\title{
Pregnancy-Induced hypertension
}

\author{
Evangelia Kintiraki, ${ }^{1}$ Sophia Papakatsika, ${ }^{2}$ George Kotronis, ${ }^{2}$ \\ Dimitrios G. Goulis, ${ }^{1}$ Vasilios Kotsis ${ }^{2}$
}

${ }^{1}$ Unit of Reproductive Endocrinology and Unit of Human Reproduction, First Department of Obstetrics and Gynecology,

${ }^{2}$ Third Department of Internal Medicine, Medical School, Aristotle University of Thessaloniki, Thessaloniki, Greece

\begin{abstract}
Pregnancy-induced hypertension (PIH) complicates 6-10\% of pregnancies. It is defined as systolic blood pressure (SBP) $>140 \mathrm{mmHg}$ and diastolic blood pressure (DBP) $>90 \mathrm{mmHg}$. It is classified as mild (SBP 140-149 and DBP 90-99 mmHg), moderate (SBP 150-159 and DBP 100$109 \mathrm{mmHg}$ ) and severe (SBP $\geq 160$ and $D B P \geq 110 \mathrm{mmHg}$ ). PIH refers to one of four conditions: a) pre-existing hypertension, b) gestational hypertension and preeclampsia (PE), c) pre-existing hypertension plus superimposed gestational hypertension with proteinuria and d) unclassifiable hypertension. PIH is a major cause of maternal, fetal and newborn morbidity and mortality. Women with PIH are at a greater risk of abruptio placentae, cerebrovascular events, organ failure and disseminated intravascular coagulation. Fetuses of these mothers are at greater risk of intrauterine growth retardation, prematurity and intrauterine death. Ambulatory blood pressure monitoring over a period of $24 \mathrm{~h}$ seems to have a role in predicting deterioration from gestational hypertension to PE. Antiplatelet drugs have moderate benefits when used for prevention of PE. Treatment of PIH depends on blood pressure levels, gestational age, presence of symptoms and associated risk factors. Non-drug management is recommended when SBP ranges between 140-149 $\mathrm{mmHg}$ or DBP between 90-99 $\mathrm{mmHg}$. Blood pressure thresholds for drug management in pregnancy vary between different health organizations. According to $2013 \mathrm{ESH} / \mathrm{ESC}$ guidelines, antihypertensive treatment is recommended in pregnancy when blood pressure levels are $\geq \mathbf{1 5 0 / 9 5} \mathbf{m m H g}$. Initiation of antihypertensive treatment at values $\geq 140 / 90 \mathrm{mmHg}$ is recommended in women with a) gestational hypertension, with or without proteinuria, b) pre-existing hypertension with the superimposition of gestational hypertension or c) hypertension with asymptomatic organ damage or symptoms at any time during pregnancy. Methyldopa is the drug of choice in pregnancy. Atenolol and metoprolol appear to be safe and effective in late pregnancy, while labetalol has an efficacy comparable to methyldopa. Angiotensin-converting enzyme (ACE) inhibitors and angiotensin II antagonists are contraindicated in pregnancy due to their association with increased risk of fetopathy.
\end{abstract}

Key words: Antihypertensive treatment, Gestational hypertension, Methyldopa, Pre-eclampsia, Pregnancy-induced hypertension 


\section{INTRODUCTION}

\section{Definition and classification}

Pregnancy-induced hypertension (PIH) complicates about $6-10 \%$ of pregnancies. ${ }^{1}$ It is defined as systolic blood pressure (SBP) $>140 \mathrm{mmHg}$ and diastolic blood pressure (DBP) $>90 \mathrm{mmHg}$. It is classified as mild (SBP 140-149 and DBP 90-99 mmHg), moderate (SBP 150-159 and DBP 100-109 mmHg) and severe $(\mathrm{SBP} \geq 160 \text { and } \mathrm{DBP} \geq 110 \mathrm{mmHg})^{2}$

According to the Canadian Hypertension Society, PIH refers to one of four conditions: a) pre-existing hypertension, b) gestational hypertension and PE, c) pre-existing hypertension plus superimposed gestational hypertension with proteinuria and d) unclassifiable hypertension, as is shown in Table $1 .^{3}$

\section{Epidemiology}

An epidemiological study in the USA over the period 1995-2004 showed that gestational hypertension and PE were the most commonly diagnosed hypertensive conditions in pregnancy, whereas pre-existing hypertension was much rarer. ${ }^{4}$ Studies from Europe revealed a prevalence of preeclampsia at $2.3-3 \%{ }^{5,6}$

\section{Complications}

According to the WHO, PIH is one of the main causes of maternal, fetal and neonatal mortality and morbidity. ${ }^{1}$ It is the most common cause of maternal death in Europe. ${ }^{7}$ In a retrospective study over the period 2000-2009 in a tertiary center in India, PIH was the third cause of maternal death. In a similar study, over the period 1996-2009 in Henan Province, China, PIH was the second cause of maternal death. One tenth of maternal deaths in Africa and one quarter in Latin America are due to PIH-associated complica- tions. ${ }^{1,8,9}$ Another study showed that the most common cause of mortality in cases of preeclampsia was haemolysis, elevated liver enzymes and low platelet count (HELLP) or partial HELLP syndrome (83.3\%). Haemorrhagic stroke and pulmonary edema have been reported as the most common causes of death in patients with eclampsia, accounting for as many as $60 \%$ of all eclampsia-related deaths. ${ }^{10}$

Other maternal short-term complications include central nervous system dysfunction, hepatocellular injury, thrombocytopenia, acute disseminated intravascular coagulation (DIC), oliguria, pulmonary edema, cerebrovascular events and placental abruption. ${ }^{11-14}$ In one study of 4,188 women with preeclampsia the incidence of one or more systemic complications was $6 \%$. Haematologic complications were most common and the incidence of placental abruption was $2.8 \%{ }^{15}$

$\mathrm{PIH}$-associated complications are more frequent in early-onset ( $<$ gestational week 32) compared to late-onset PE. ${ }^{16}$ A comparative study showed that women with PE and superimposed PE have the same rates of perinatal complications. By contrast, women with superimposed PE had a significantly higher risk of intervention-related complications, such as delivery at $<$ gestational week 34 , caesarean delivery and neonatal intensive care unit admission. ${ }^{17}$

Fetal/neonatal short-term complications include intrauterine growth restriction (IUGR), small for gestational age (SGA) neonate, low birth weight neonate, preterm birth, intrauterine and perinatal death. ${ }^{18,19}$ In one study of 17,933 stillbirths, 9.2\% were by pregnancies complicated by hypertensive disorders of pregnancy. ${ }^{20}$ One study from Greece revealed increased neonatal adverse outcomes in infants of preeclamptic women as compared to those of

Table 1. PIH classification ${ }^{3,151,152}$

Pre-existing hypertension (1-5\%)

Gestational hypertension and preeclampsia (PE, 2-8\%)

Pre-existing hypertension plus superimposed gestational hypertension with proteinuria (previously known as chronic hypertension with superimposed preeclampsia)

Unclassifiable hypertension

\footnotetext{
$<20^{\text {th }}$ gestational week, persists more than 42 days postpartum, $+/$ - proteinuria

$>20^{\text {th }}$ gestational week, resolves within 42 days postpartum, + /- significant proteinuria, poor organ perfusion

$>20^{\text {th }}$ gestational week, further worsening of blood pressure and protein excretion, up to $3 \mathrm{~g} / 24 \mathrm{~h}$
}

$>20^{\text {th }}$ gestational week, $+/$ - systemic manifestations, reassessment is necessary at or after $42 \mathrm{~d}$ postpartum 
normotensive women. ${ }^{21}$ A retrospective study showed that hospital-based continuous prenatal care reduced the risk of pre-term delivery and impaired fetal growth in pregnancies complicated by PE. ${ }^{22}$

Concerning long-term health risk, several studies demonstrated that women with PIH are at greater risk of other medical conditions, such as hypertension, cardiovascular disease, diabetes mellitus and kidney disease in later life..$^{23,24}$ One study of 3,593 women with preeclampsia during their first singleton pregnancy pointed to a positive association of hypertensive diseases of pregnancy with diseases related to hypertension in later life. ${ }^{25}$

The risk of diabetes in later life was 2-fold higher in women with PE or gestational hypertension compared with women without them. ${ }^{26}$ Long-term health risk seems to be increased among the offspring of pregnancies complicated by PIH. These conditions include higher blood pressure in childhood and adulthood and a tendency towards impaired lipid profile, a 2-fold higher stroke risk, lower cognitive ability and mental disorders in later life. ${ }^{27-31}$

\section{Risk factors}

Hypertension, collagen vascular disease, obesity, black race, insulin resistance, diabetes mellitus, gestational diabetes, increased serum testosterone concentrations and thrombophilia are considered risk factors for PIH. ${ }^{32,33}$

A recent epidemiological study showed that Black and some Hispanic women had markedly increased risk for all hypertensive disorders in pregnancy compared to non-Hispanic white women, while Asian women were at decreased risk. The same study disclosed a positive correlation between pre-pregnancy weight and risk of PIH, whereas parity and smoking were protective for PE development. ${ }^{4}$ The data for parity are conflicting, as both nulliparity and multiparity seems to predispose to higher risk for PE. ${ }^{34-36}$

Maternal age $>30$ years and increased body mass index (BMI) were found to be positively correlated to risk for PIH in Arab women. ${ }^{37}$ Increased pre-pregnancy BMI was also a risk factor for PE in twin pregnancies. ${ }^{38}$ In addition, above-average weight gain during pregnancy was positively correlated to PE risk. ${ }^{36}$ Personal and family history of PE are considered significant risk factors for $\mathrm{PE}$ in pregnancy. ${ }^{39-41}$
Anti-phospholipid syndrome (APS), an autoimmune condition characterized by recurrent thrombosis, is widely recognized as a risk factor for several obstetric complications, including PIH. Approximately one third of women with APS will develop PE. ${ }^{42,43}$

Two recent meta-analyses concluded that low maternal vitamin D concentrations are associated with increased risk of PE. ${ }^{44,45}$

\section{PHYSIOLOGY: CARDIOVASCULAR CHANGES DURING PREGNANCY}

Significant cardiovascular and haemodynamic changes occur early in pregnancy in order to provide enough blood for the embryo and maintain normal fetal intrauterine growth. Such changes include increased maternal plasma volume, cardiac output and heart rate, and decreased maternal systemic vascular resistance and arterial blood pressure. ${ }^{46}$

The expansion of maternal plasma volume is due to stimulation of the renin-angiotensin-aldosterone system. As a compensatory mechanism, vasodilator synthesis is increased in order to maintain normotension. ${ }^{47}$ Such vasodilators include the kallikrein-kinin system, prostacyclin, nitric oxide and vascular-endothelial growth factor (VEGF). ${ }^{48-50}$

In addition to the functional adaptation of the maternal cardiovascular system, structural changes also occur during pregnancy. This adaptive remodelling results in cardiac hypertrophy that enables the heart to cope with the increased demands of gestation. This hypertrophy is reversible and is not associated with long-term cardiovascular dysfunction. ${ }^{51}$

In summary, haemodynamic changes during pregnancy include a reduction of systolic, diastolic and mean arterial blood pressure in the second trimester followed by a slight increase in the third, a reduction of total vascular resistance, especially in the second trimester, and an increase of cardiac output. ${ }^{52}$

\section{PATHOPHYSIOLOGY}

$\mathrm{PIH}$ and especially PE is considered to be a multifactorial disease. Many theories have been developed about its pathogenesis. Their common characteristic is the central role of the placenta. The modified theory of the "two-stage model" suggests that abnormal 
placental implantation, vascularization or function together with the contribution of maternal factors can lead to PE. ${ }^{53}$ Factors that have been implicated in PE pathophysiology are cardiovascular maladaptation and vasoconstriction, genetic predisposition, immunologic intolerance between feto-placental and maternal tissue, platelet activation and vascular endothelial dysfunction. ${ }^{54}$ Moreover, coexisting metabolic factors can contribute to endothelial dysfunction, and hyperlipidaemia and insulin resistance have been associated with preeclampsia. ${ }^{55-57}$

Immune factors, such as auto-antibodies, oxidative stress and natural killer (NK)-cell abnormalities, cause placental dysfunction and impaired placental perfusion. The latter acts as a stimulus of placental release of anti-angiogenic and inflammatory mediators that eventually cause endothelial dysfunction and organ damage.$^{58}$ Increased numbers of activated monocytes and macrophages have been described in the endometrium of women with PE. ${ }^{59} \mathrm{~A}$ misbalance between antioxidant and pre-oxidant factors and increased production of ROS results in vascular endothelium dysfunction in women with PE. ${ }^{60}$ One study showed that women with early-onset severe preeclampsia have increased NK cell function related to cytokine production. ${ }^{61}$

Angiogenic factors, such as VEGF family members (VEGF, PIGF), angiopoietins and their receptors, are thought to be significant for the regulation of placental growth and vascular development. ${ }^{62}$ Angiopoietin 1 binds to Tie receptors, whereas angiopoietin 2 acts as an antagonistic ligand. ${ }^{63}$ Impaired expression of demonstrated decreased VEGF levels in the umbilical cord from pregnancies complicated by hypertension as compared to normal pregnancies. ${ }^{66}$ The angiopoietin 1/angiopoietin 2 ratio was found significantly lower in women who developed preeclampsia than in normal pregnant women. ${ }^{67}$

Anti-angiogenic factors, such as sFlt1 [soluble Flt1 (fms-like tyrosine kinase 1)] and soluble endoglin (sEng), inhibit angiogenesis and promote vascular dysfunction. sFlt-1 binds to VEGF and PlGF, and sEng impairs binding of TGF- $\beta 1$ to its receptor, blocking their actions. ${ }^{68,69}$ Both of them are expressed by normal placenta. ${ }^{70,71}$ Many studies have amplified the theory of the misbalance of circulating angiogenic factors in $\mathrm{PE}$ and the sFlt-1/PlGF ratio has been proposed as an additional diagnostic or predictive tool for PE. ${ }^{72-74}$ A meta-analysis showed increased concentrations of placental and maternal sFlt1 and sEng and decreased concentrations of PIGF in pregnancies which developed PE. VEGF was lower, though not significantly different, between the women who developed PE and those who did not. ${ }^{75}$

Several studies have shown an increased risk of PIH and $\mathrm{PE}$ in pregnancies with positive familial history of PE. ${ }^{76,77}$ The latter implies a genetic predisposition. Many single nucleotide polymorphisms (SNPs) in candidate genes of clotting factors, vascular growth factors, vasoactive proteins, oxidative stress related factors, immunoactive mediators and components of the renin-angiotension-aldodterone system have been associated with PE development. ${ }^{78,79}$

\section{FOLLOW-UP}

The assessment of women with pregnacies complicated by PIH includes clinical follow-up, serological investigation and fetal ultrasound evaluation..$^{80,81}$ The type and frequency of follow-up depends on the kind and severity of the hypertensive disorder.

Clinical follow-up includes blood pressure measurements using mercury sphygmomanometry (Korotkoff phase $\mathrm{V}$ ), in the sitting position, and evaluation of any signs or symptoms indicative of clinical deteroriation. ${ }^{82}$ Biochemical and urine tests include urine dipstick, urinalysis for proteinuria, if urine dipstick has $>1+$, full blood count (haematocrit, haemoglobin, platelets), liver enzymes, serum urea, creatinine, eloctrolytes and serum uric acid. Similarly, frequency of fetal monitoring depends on the type of hypertensive disorder. In pregnancies complicated by chronic hypertension, fetal ultrasound, amniotic fluid volume assessment and umbilical artery Doppler velocimetry are recommended at gestational weeks 28-30 and 3234. Cardiotocography is suggested if fetal activity is abnormal. Fetal follow-up is also recommended for cases of mild or moderate gestational hypertension. For cases with severe gestational hypertension or PE, fetal ultrasound, amniotic fluid volume assessment and umbilical Doppler velocimetry is recommended to be performed not more frequently than every two weeks. Cardiotocography is recommended if abnormal 
fetal activity, vaginal bleeding or deterioration of the pre-existing condition is observed. ${ }^{83}$

Non-invasive ambulatory blood pressure monitoring (ABPM) seems to be a useful tool for the diagnosis, differential diagnosis and follow-up of PIH. It contributes to identification of cases with white-coat hypertension (WCH), prediction of $\mathrm{PE}$, prognosis in late pregnancy and treatment modification. ${ }^{84-88}$

$\mathrm{WCH}$ refers to elevated blood pressure measurements when "in clinic", while "out of clinic" measurements are normal. $\mathrm{WCH}$ in pregnancy is a frequent and benign condition with good prognosis and no apparent need for antihypertensive treatment. Despite that, a small proportion of patients with $\mathrm{WCH}$ in early pregnancy will develop PE later in pregnancy. ${ }^{89,90}$ Consequently, it is essential to differentiate $\mathrm{WCH}$ from $\mathrm{PIH}$, thus avoiding exposing these women to the possible adverse effects of antihypertensive treatment as well as unnecessary caesarean sections. In addition, detection of that group of women with $\mathrm{WCH}$ who are going to develop PE is important for pregnancy outcome. ABPM contributes to the achievement of both the above goals, in parallel with the evaluation of treatment efficacy. ${ }^{84,89,91,92}$

\section{TREATMENT}

Treatment of PIH depends on blood pressure levels, gestational age, presence of symptoms and associated risk factors.

\section{Mild to moderate hypertension}

Data for the treatment of mild to moderate PIH are controversial, making it difficult to formulate clear recommendations..$^{80,81,93,94}$

Randomized controlled trials (RCTs) that compared pharmaceutical treatments with placebo or no treatment in mild cases of PIH had conflicting results. Prospective controlled studies of metoprololhydralazine, nifedipine and labetalol-methyldopa treatment administered to pregnant women with mild $\mathrm{PIH}$, unclassifiable hypertension or mild PE showed no significant improvement of pregnancy outcome as compared to the non-treated group. ${ }^{95-98}$ Labetalol had no effect on development of proteinuria in a trial of 114 women with PIH and nifedipine had no effect on PE-related hypocalciuria as compared to the control group. ${ }^{99,100}$ Other RCTs resulted in better pregnancy outcome in the treated groups. In contrast to the above findings, atenolol and labetalol prevented proteinuria in the treatment group as compared to the control group. ${ }^{101-103} \mathrm{RCTs}$ with methyldopa pointed to better pregnancy outcome in cases of mild PIH and mild PE with regard to mid-pregnancy abortions and progression to severe PE, respectively. ${ }^{104,105}$ Another trial of methyldopa in mild PIH demonstrated a significant prolongation of pregnancy, by about 10.3 days, with no adverse effect on birth weight. ${ }^{106}$ An RCT of 100 pregnant women with mild PIH who were treated either with methyldopa or labetalol and 50 controls confirmed the positive effect of antihypertensive treatment on pregnancy outcome. Maternal outcomes that were significantly improved by the antihypertensive treatment were progression to severe $\mathrm{PIH}$, proteinuria, hospitalization before term and delivery by caesarean section, whereas fetal/neonatal outcomes were SGA, preterm birth and admission to neonatal unit. ${ }^{107}$

Early treatment with clonidine plus hydralazine compared to the non-treatment group prevented premature delivery in primigravid diagnosed with mild PIH $(<170 / 110 \mathrm{mmHg}) .{ }^{108}$ Treatment with nifedipine in cases of mild PE had a positive effect on renal function with significant reduction of urea, creatinine and $24 \mathrm{~h}$ urine protein in the treatment group. ${ }^{109}$ Isradipine treatment was found to have no adverse affect on maternal kidney or liver function or blood flow in the umbilical artery. ${ }^{110}$

Regarding neonatal glucose concentrations, there was no significant difference between mothers who received either isradipine, atenolol or low sodium diet (control group). ${ }^{111}$ As far as fetal growth is concerned, atenolol and labetalol treatment in mild PIH and mild PE, respectively, were associated with fetal growth restriction, whereas early antihypertensive treatment with oxprenolol had no such effect. ${ }^{112-115} \mathrm{~A}$ meta-analysis of the effect of oral antihypertensive treatment in cases of mild to moderate PIH concluded that greater decrease of blood pressure was associated with fetal growth restriction. The drugs that were used in the RCTs of this meta-regression analysis were a-methyldopa, beta-blockers, thiazides, ketanserin, hydralazine, calcium-channel blockers and clonidine. Birth weights of newborns of the mothers who took antihypertensive therapy during pregnancy were lower 
than those of the non-treated/placebo group. Decrease in mean arterial pressure of $10 \mathrm{mmHg}$ was associated with a $145 \mathrm{~g}$ decrease in mean birth weight, as found in a post-hoc analysis. ${ }^{116}$

RCTs of methyldopa treatment during pregnancy had smaller head circumference in the treatment group at birth, 2 months, 6 months and 4 years of age as compared to control groups. ${ }^{117-121}$ In contrast, an RCT with nifedipine treatment in cases of mild to moderate $\mathrm{PIH}$ exhibited no difference between the treatment and control groups as far as development and health status at 18 months of age were concerned. ${ }^{122}$

The ratio of maternal-fetal benefit to risk for fetal adverse effects, such as low birth weight, need to be further evaluated. ${ }^{116,123,124} \mathrm{~A}$ Cochrane systematic review on the control of blood pressure in mild to moderate PIH did not reach conclusive results due to insufficient data. ${ }^{125}$

In general, non-pharmacological treatment is suggested for pregnant women with mild to moderate $\mathrm{PIH}$ that do not fulfil the criteria for pharmacologic treatment. According to the WHO, lifestyle modification, such as strict bed rest and salt restriction, are not recommended in PIH or PE. ${ }^{1}$ Compliance with the recommendations for the pre-pregnancy BMIdependent indicated weight gain is essential due to the fact that both obesity and gestational weight gain are risk factors for PIH, PE or eclampsia. ${ }^{34,36,126}$ Strict follow-up and early diagnosis of progression to a more severe condition is necessary.

Women at high risk of $\mathrm{PE}$ are recommended to receive $75 \mathrm{mg}$ aspirin and calcium supplements daily, especially when dietary calcium intake is low. Vitamins C, E, D are not recommended for PE prevention due to insufficient data. ${ }^{1,127}$ Magnesium sulphate $\left(\mathrm{MgSO}_{4}\right)$ is recommended for eclampsia prevention in women with severe PE or as a supplementary treatment modality in eclampsia. ${ }^{1}$

\section{Severe hypertension}

Blood pressure thresholds for drug treatment initiation in PIH vary between different health organizations. According to the 2013 European Society of Hypertension (ESH)/European Society of Cardiology (ESC) guidelines, antihypertensive treatment in pregnancy is recommended when blood pressure levels are $\geq 150 / 95$
$\mathrm{mmHg}$ (Table 2). Initiation of antihypertensive treatment at lower levels $(\geq 140 / 90 \mathrm{mmHg})$ is suggested for women with a) gestational hypertension with or without proteinuria, b) pre-existing hypertension with the superimposition of gestational hypertension or c) hypertension with asymptomatic organ damage or symptoms at any time during pregnancy. ${ }^{127}$

The aim of antihypertensive treatment is to prevent complications, such as maternal cerebral haemorrhage and eclampsia, and allow prolongation of pregnancy. According to the National Institute of Clinical Excellence (NICE) guideline for "management of hypertensive disorders during pregnancy 2010 ", the therapeutic goal in severe $\mathrm{PIH}$ is a gradual decrease of blood pressure to $<150 / 100 \mathrm{mmHg} .{ }^{128}$

Methyldopa is considered the drug of choice in pregnancy due to its effectiveness and long safety record. Labetalol can be given intravenously in emergency cases. Calcium channel blockers (CCB), such as nifedipine per os or isradipine IV, are effective and have no major teratogenic risk. A potential synergism with $\mathrm{MgSO}_{4}$ that may induce hypotension must be taken into consideration. Atenolol and metoprolol appear to be safe and effective in late pregnancy. Hydralazine is no longer the parenteral drug of choice in emergency cases due to perinatal adverse effects and slower therapeutic response. ${ }^{129-132}$ A Cochrane review about the use of diuretics for prevention of PE and its complications disclosed no significant difference in pregnancy outcomes between the treated group and the placebo or no-drug groups. ${ }^{133}$ Angiotensin-

Table 2. ESH/ESC 2013 guidelines for hypertension in pregnancy ${ }^{127}$

\begin{tabular}{lc}
\hline Blood pressure levels & $\begin{array}{c}\text { Antihypertensive } \\
\text { treatment }\end{array}$ \\
\hline $160 / 110 \mathrm{~mm} \mathrm{Hg}$ & + \\
$\geq 150 / 95 \mathrm{~mm} \mathrm{Hg}$ (if persistent) & + \\
$\geq 140 / 90 \mathrm{~mm}+$ & + \\
a) gestational hypertension, with or & \\
without proteinuria, or & \\
b) pre-existing hypertension with & \\
the superimposition of gestational & \\
hypertension, or & \\
c) hypertension with asymptomatic organ \\
damage or symptoms at any time during \\
pregnancy
\end{tabular}


converting enzyme inhibitors (ACEIs) and angiotensin II receptor blockers (ARBs) are contraindicated in pregnancy due to their association with an increased risk of fetopathy. ${ }^{134-136}$ Women who are treated with an ACE or ARB before conception should be advised to avoid exposure to these drugs during pregnancy by replacing them with a different antihypertensive drug as soon as pregnancy is confirmed. ${ }^{128}$ Studies of pregnant women who received the above classes of drugs and animal experimental studies showed increased risk of fetal hypotension, decreased glomerular perfusion pressure, impaired renal tubular development, reduced fetal urine output or complete anuria and oligohydramnios, limb contractures, pulmonary hypoplasia, cranio-facial deformation and impaired ossification, intrauterine growth restriction and decreased placental and umbilical perfusion. Epidemiological studies demonstrated an increased risk of congenital malformations among neonates of mothers who received ACEIs and ARBs during pregnancy compared to controls. ${ }^{137}$

Several RCTs compared different antihypertensive drugs in pregnancy. A Cochrane systematic review included 24 RCTs that compared at least two antihypertensive drugs. ${ }^{138}$ The review did not come to a clear conclusion due to insufficient data. Hydralazine as compared to nifedipine and isradipine was seen to be less effective as regards persistent high blood pressure. No difference was detected between hydralazine and prostacyclin. Ketanserin is a selective S2-serotoninergic antagonist exerting alpha-1 receptor antagonistic action, especially with higher doses of the drug. It inhibits the vasoconstriction and platelet aggregation induced by serotonin. ${ }^{139}$

Hydralazine was associated with lower risk for persistent high blood pressure as compared to ketanserin but with increased rate of adverse effects. Urapidil is an alpha-1 receptor antagonist with agonistic action at serotonin $5-\mathrm{HT}_{1 \mathrm{~A}}$ receptors. It also has a central sympatholytic effect mediated via stimulation of serotonin $5 \mathrm{HT}_{1 \mathrm{~A}}$ receptors in the central nervous system. It reduces blood pressure by decreasing peripheral vascular resistance. ${ }^{140}$ Studies comparing hydralazine to urapidil provided insufficient data. One prospective study of 100 women with severe PIH showed that urapidil was effective in $80 \%$ of cases. ${ }^{141}$

Data were also insufficient as regards the com- parison of labetalol to hydralazine, methyldopa and nicardipine. Labetalol was associated with marginally less hypotension and caesarian section rate compared to diazoxide. $\mathrm{MgSO}_{4}$ had a higher risk of persistent high blood pressure, of maternal respiratory distress and of postpartum haemorrhage but a lower risk of eclampsia compared to nimodipine. Isosorbide was associated with lower frequency of caesarian section than $\mathrm{MgSO}_{4}$.

An RCT of 200 pregnant women who were treated with hydralazine IV or labetalol for severe PIH resulted in a significantly higher rate of palpitations and maternal tachycardia in the hydralazine-treated group and higher rate of hypotension and bradycardia in the labetalol-treated group. ${ }^{142}$ Another smaller $(n=16)$ trial of hydralazine or labetalol in acute severe PIH revealed the high effectiveness of both drugs, with no effect of either of them on fetal Doppler. ${ }^{143}$ In contrast, the group that received hydralazine had a significant increase in uterine arteries resistance. Hydralazine IV as compared to mini bolus diazoxide resulted in a significantly higher rate of persistent hypertension. ${ }^{144}$ The latter was also observed in a trial of hydralazine IV or nifedipine per os in hypertensive crisis. Another smaller study of dihydralazine and urapidil found no difference as regards effectiveness between the two drugs. ${ }^{145}$ Treatment with nitroglycerine IV plus plasma volume expansion and $\mathrm{MgSO}_{4}$ as compared to sublingual nifedipine plus plasma volume expansion and $\mathrm{MgSO}_{4}$ showed no difference in effectiveness or maternal and fetal-neonatal adverse effects. ${ }^{146}$ Finally, a double-blind RCT of nifedipine per os versus labetalol IV resulted in no significant difference in the time needed to achieve the therapeutic goal or the overall efficacy between the two drugs. ${ }^{147}$

Acute severe hypertension in pregnancy is considered a medical emergency and requires hospitalization. Labetalol, hydralazine and nifedipine are used as first line treatment. ${ }^{148} \mathrm{~A}$ double-blind randomized trial compared the effectiveness of oral nifedipine and intravenous labetalol in pregnant women with gestational hypertension and $\mathrm{BP} \geq 160 / 110 \mathrm{mmHg}$. No significant difference in BP decrease was found between the two groups. ${ }^{149}$ Intravenous nitroglycerin, oral methyldopa or oral clonidine can be used as second line treatment. ${ }^{148}$ Magnesium sulfate can be used in combination with an antihypertensive agent 
Table 3. Treatment of severe hypertension (Modified by SOGC Clinical Practice Guideline 2014) ) $^{148}$

\begin{tabular}{lcccc}
\hline $\begin{array}{l}\text { Anti-hypertensive } \\
\text { agent }\end{array}$ & Dosage & Onset & Duration & Comments \\
\hline Labetalol & $\begin{array}{r}20 \mathrm{mg} \mathrm{IV} \text {, repeat } 20 \mathrm{mo} 80 \mathrm{mg} \text { IV q } 30 \mathrm{~min}, \\
\text { or } 1 \mathrm{to} 2 \mathrm{mg} / \mathrm{min}, \mathrm{max} 300 \mathrm{mg} \text { (then switch to oral) }\end{array}$ & $5 \mathrm{~min}$ & $4 \mathrm{~h}$ & $\begin{array}{c}\text { Contra indications: } \\
\text { asthma, cardiac failure }\end{array}$ \\
Nifedipine & 5 to $10 \mathrm{mg}$ capsule to be swallowed or bitten, every $30 \mathrm{~min}$ & $5-10 \mathrm{~min}$ & $6 \mathrm{~h}$ & \\
Hydralazine & $\begin{array}{r}5 \mathrm{mg} \mathrm{IV} \text {, repeat } 5 \text { to } 10 \mathrm{mg} \text { IV every } 30 \mathrm{~min}, \text { or } 0.5 \\
\text { to } 10 \mathrm{mg} / \mathrm{hr} \text { IV, to a maximum of } 20 \mathrm{mg} \text { IV (or } 30 \mathrm{mg} \mathrm{IM})\end{array}$ & $5 \mathrm{~min}$ & $\begin{array}{c}\text { Increased risk of } \\
\text { maternal hypotension }\end{array}$ \\
\hline
\end{tabular}

for the prophylaxis of seizures in cases of severe preeclampsia or eclampsia. ${ }^{150}$

Therapeutic options for severe hypertension are shown in Table $3 .{ }^{148}$

\section{CONCLUSIONS}

In conclusion, $\mathrm{PIH}$ is a common health problem with adverse effects for both mother and fetus/neonate. It is believed to be a multifactorial health condition the pathogenetic mechanism of which is not as yet fully understood. More studies clarifying the latter will also contribute to more effective medical treatment and optimization of pregnancy outcome. The use of antihypertensive treatment, especially in cases of mild hypertension, is meanwhile of great concern. More randomized controlled studies are necessary for further evaluation of the ratio of maternal-fetal benefit to risk for fetal adverse effects.

\section{CONFLICT OF INTERESTS}

All authors declare no potential conflicts of interest.

\section{REFERENCES}

1. World Health Organization, 2011 WHO Recommendations for prevention and treatment of pre-eclampsia and eclampsia.

2. Visintin C, Mugglestone MA, Almerie MQ, Nherera LM, James D, Walkinshaw S, 2010 Management of hypertensive disorders during pregnancy: summary of NICE guidance. BMJ 341: c2207.

3. Helewa ME, Burrows RF, Smith J, Williams K, Brain P, Rabkin SW, 1997 Report of the Canadian Hypertension Society Consensus Conference: 1. Definitions, evaluation and classification of hypertensive disorders in pregnancy. CMAJ 157: 715-725.

4. Savitz DA, Danilack VA, Engel SM, Elston B, Lipkind
HS, 2013 Descriptive epidemiology of chronic hypertension, gestational hypertension, and preeclampsia in New York State, 1995-2004. Matern Child Health J 18: 829-838.

5. Schneider S, Freerksen N, Maul H, Roehrig S, Fischer B, Hoeft B, 2011 Risk groups and maternal-neonatal complications of preeclampsia--current results from the national German Perinatal Quality Registry. J Perinat Med 39: 257-265.

6. Klungsoyr K, Morken NH, Irgens L, Vollset SE, Skjaerven R, 2012 Secular trends in the epidemiology of preeclampsia throughout 40 years in Norway: prevalence, risk factors and perinatal survival. Paediatr Perinat Epidemiol 26: 190-198.

7. Wildman K, Bouvier-Colle MH, 2004 Maternal mortality as an indicator of obstetric care in Europe. BJOG 111: 164-169.

8. Khumanthem PD, Chanam MS, Samjetshabam RD, 2012 Maternal mortality and its causes in a tertiary center. J Obstet Gynaecol India 62: 168-171.

9. You F, Huo K, Wang R, et al, 2012 Maternal mortality in Henan Province, China: changes between 1996 and 2009. PLoS One 7: e47153.

10. Chhabra S, Kakani A, 2007 Maternal mortality due to eclamptic and non-eclamptic hypertensive disorders: a challenge. J Obstet Gynaecol 27: 25-29.

11. Brichant G, Dewandre PY, Foidart JM, Brichant JF, 2010 Management of severe preeclampsia. Acta Clin Belg 65: 163-169.

12. Duley L, 2009 The global impact of pre-eclampsia and eclampsia. Semin Perinatol 33: 130-137.

13. Rattray DD, O'Connell CM, Baskett TF, 2012 Acute disseminated intravascular coagulation in obstetrics: a tertiary centre population review (1980 to 2009). J Obstet Gynaecol Can 34: 341-347.

14. Matsuda Y, Hayashi K, Shiozaki A, Kawamichi Y, Satoh S, Saito S, 2011 Comparison of risk factors for placental abruption and placenta previa: case-cohort study. J Obstet Gynaecol Res 37: 538-546.

15. Bhattacharya S, Campbell DM, 2005 The incidence of severe complications of preeclampsia. Hypertens Pregnancy 24: 181-190.

16. Gong YH, Jia J, Lu DH, Dai L, Bai Y, Zhou R, 2012 
Outcome and risk factors of early onset severe preeclampsia. Chin Med J (Engl) 125: 2623-2627.

17. Tuuli MG, Rampersad R, Stamilio D, Macones G, Odibo AO, 2011 Perinatal outcomes in women with preeclampsia and superimposed preeclampsia: do they differ? Am J Obstet Gynecol 204: 508e1-7.

18. Bakker R, Steegers EA, Hofman A, Jaddoe VW, 2011 Blood pressure in different gestational trimesters, fetal growth, and the risk of adverse birth outcomes: the generation R study. Am J Epidemiol 174: 797-806.

19. Yucesoy G, Ozkan S, Bodur H, et al, 2005 Maternal and perinatal outcome in pregnancies complicated with hypertensive disorder of pregnancy: a seven year experience of a tertiary care center. Arch Gynecol Obstet 273: 43-49.

20. Ahmad AS, Samuelsen SO, 2012 Hypertensive disorders in pregnancy and fetal death at different gestational lengths: a population study of 2121371 pregnancies. BJOG 119: 1521-1528.

21. Masoura S, Kalogiannidis I, Margioula-Siarkou C, et al, 2012 Neonatal outcomes of late preterm deliveries with pre-eclampsia. Minerva 64: 109-115.

22. Liu CM, Chang SD, Cheng PJ, 2012 Relationship between prenatal care and maternal complications in women with preeclampsia: implications for continuity and discontinuity of prenatal care. Taiwan J Obstet Gynecol 51: 576-582.

23. Mitka M, 2013 Any hypertension during pregnancy raises risk for several chronic diseases: JAMA 309: 971-972.

24. Mannisto T, Mendola P, Vaarasmaki M, et al, 2013 Elevated blood pressure in pregnancy and subsequent chronic disease risk. Circulation 127: 681-690.

25. Wilson BJ, Watson MS, Prescott GJ, et al, 2003 Hypertensive diseases of pregnancy and risk of hypertension and stroke in later life: results from cohort study. BMJ 326: 845 .

26. Feig DS, Shah BR, Lipscombe LL, et al, 2013 Preeclampsia as a Risk Factor for Diabetes: A PopulationBased Cohort Study. PLoS Med 10: e1001425.

27. Tuovinen S, Raikkonen K, Pesonen AK, et al, 2012 Hypertensive disorders in pregnancy and risk of severe mental disorders in the offspring in adulthood: the Helsinki Birth Cohort Study. J Psychiatr Res 46: 303-310.

28. Miettola S, Hartikainen AL, Vaarasmaki M, et al, 2013 Offspring's blood pressure and metabolic phenotype after exposure to gestational hypertension in utero. Eur J Epidemiol 28: 87-98.

29. Kajantie E, Eriksson JG, Osmond C, Thornburg K, Barker DJ, 2009 Pre-eclampsia is associated with increased risk of stroke in the adult offspring: the Helsinki birth cohort study. Stroke 40: 1176-1180.

30. Tuovinen S, Raikkonen K, Kajantie E, et al, 2012 Hypertensive disorders in pregnancy and cognitive decline in the offspring up to old age. Neurology 79 :
1578-1582.

31. Tuovinen S, Eriksson JG, Kajantie E, et al, 2013 Maternal hypertensive disorders in pregnancy and selfreported cognitive impairment of the offspring 70 years later: the Helsinki Birth Cohort Study. Am J Obstet Gynecol 208: 200e1-200e9.

32. Roberts JM, Pearson G, Cutler J, Lindheimer M, 2003 Summary of the NHLBI working group on research on hypertension during pregnancy. Hypertension 41: 437-445.

33. Koual M, Abbou H, Carbonnel M, Picone O, Ayoubi JM, 2013 Short-term outcome of patients with preeclampsia. Vasc Health Risk Manag 9: 143-148.

34. Coghill AE, Hansen S, Littman AJ, 2011 Risk factors for eclampsia: a population-based study in Washington State, 1987-2007. Am J Obstet Gynecol 205: 553e1-7.

35. Anderson NH, Sadler LC, Stewart AW, Fyfe EM, McCowan LM, 2012 Ethnicity, body mass index and risk of pre-eclampsia in a multiethnic New Zealand population. Aust N Z J Obstet Gynaecol 52: 552-558.

36. Schneider S, Freerksen N, Maul H, Roehrig S, Fischer B, Hoeft B, 2011 Risk groups and maternal-neonatal complications of preeclampsia--current results from the national German Perinatal Quality Registry. J Perinat Med 39: 257-265.

37. Bener A, Saleh NM, 2013 The impact of socio-economic, lifestyle habits, and obesity in developing of pregnancyinduced hypertension in fast-growing country: global comparisons. Clin Exp Obstet Gynecol 40: 52-57.

38. Lucovnik M, Tul N, Verdenik I, Novak Z, Blickstein I, 2012 Risk factors for preeclampsia in twin pregnancies: a population-based matched case-control study. J Perinat Med 40: 379-382.

39. Mostello D, Catlin TK, Roman L, Holcomb WL Jr, Leet T, 2002 Preeclampsia in the parous woman: who is at risk? Am J Obstet Gynecol 187: 425-429.

40. Dalmaz CA, Santos KG, Botton MR, Roisenberg I, 2011 Risk factors for hypertensive disorders of pregnancy in southern Brazil. Rev Assoc Med Bras 57: 692-696.

41. Melamed N, Hadar E, Peled Y, Hod M, Wiznitzer A, Yogev Y, 2012 Risk for recurrence of preeclampsia and outcome of subsequent pregnancy in women with preeclampsia in their first pregnancy. J Matern Fetal Neonatal Med 25: 2248-2251.

42. Danza A, Ruiz-Irastorza G, Khamashta M, 2012 Antiphospohlipid syndrome in obstetrics. Best Pract Res Clin Obstet Gynaecol 26: 65-76.

43. Clark EA, Silver RM, Branch DW, 2007 Do antiphospholipid antibodies cause preeclampsia and HELLP syndrome? Curr Rheumatol Rep 9: 219-925.

44. Wei SQ, Qi HP, Luo ZC, Fraser WD, 2013 Maternal vitamin $\mathrm{D}$ status and adverse pregnancy outcomes: a systematic review and meta-analysis. J Matern Fetal Neonatal Med 26: 889-899.

45. Tabesh M, Salehi-Abargouei A, Tabesh M, Esmaillzadeh A, 2013 Maternal Vitamin D Status and Risk of Pre- 
Eclampsia: A Systematic Review and Meta-Analysis. J Clin Endocrinol Metab 98: 3165-173.

46. Ouzounian JG, Elkayam U, 2012 Physiologic changes during normal pregnancy and delivery. Cardiol Clin 30: 317-329.

47. Valdes G, Corthorn J, 2011 Challenges posed to the maternal circulation by pregnancy. Integr Blood Press Control 4: 45-53.

48. Valdes G, Kaufmann P, Corthorn J, Erices R, Brosnihan KB, Joyner-Grantham J, 2009 Vasodilator factors in the systemic and local adaptations to pregnancy. Reprod Biol Endocrinol 7: 79.

49. Seeliger C, Brueckmann A, Schleussner E, 2012 Maternal endothelial function in the course of pregnancy and postpartum - ultrasound-based longitudinal assessment using flow-mediated dilatation (FMD). Ultraschall Med 33: E126-131.

50. van Drongelen J, Hooijmans CR, Lotgering FK, Smits $\mathrm{P}$, Spaanderman ME, 2012 Adaptive changes of mesenteric arteries in pregnancy: a meta-analysis. Am J Physiol Heart Circ Physiol 303: H639-657.

51. Hunter S, Robson SC, 1992 Adaptation of the maternal heart in pregnancy. Br Heart J 68: 540-543.

52. Savu O, Jurcut R, Giusca S, et al, 2012 Morphological and functional adaptation of the maternal heart during pregnancy. Circ Cardiovasc Imaging 5: 289-297.

53. Roberts JM, Hubel CA, 2009 The two stage model of preeclampsia: variations on the theme. Placenta 30: Suppl A: S32-37.

54. Santillan MK, Santillan DA, Sigmund CD, Hunter SK, 2009 From molecules to medicine: a future cure for preeclampsia? Drug News Perspect 22: 531-541.

55. Al-Nasiry S, Ghossein-Doha C, Polman S, et al, 2014 Metabolic syndrome after pregnancies complicated by pre-eclampsia or small for gestational age: a retrospective cohort. BJOG: DOI: 10.1111/1471-0528.13117.

56. Abhari FR, Ghanbari Andarieh M, Farokhfar A, Ahmady S, 2014 Estimating rate of insulin resistance in patients with preeclampsia using HOMA-IR index and comparison with nonpreeclampsia pregnant women. Biomed Res Int 2014: 140851.

57. Spracklen CN, Smith CJ, Saftlas AF, Robinson JG, Ryckman KK, 2014 Maternal hyperlipidemia and the risk of preeclampsia: a meta-analysis. Am J Epidemiol 180: 346-358.

58. Wang A, Rana S, Karumanchi SA, 2009 Preeclampsia: the role of angiogenic factors in its pathogenesis. Physiology (Bethesda) 24: 147-158.

59. Faas MM, Spaans F, De Vos P, 2014 Monocytes and macrophages in pregnancy and pre-eclampsia. Front Immunol 5: 298.

60. Sanchez-Aranguren LC, Prada CE, Riano-Medina CE, Lopez M, 2014 Endothelial dysfunction and preeclampsia: role of oxidative stress. Front Immunol 5: 372.

61. Bueno-Sanchez JC, Agudelo-Jaramillo B, EscobarAguilerae LF, et al, 2013 Cytokine production by non- stimulated peripheral blood NK cells and lymphocytes in early-onset severe pre-eclampsia without HELLP. J Reprod Immunol 97: 223-231.

62. Burton GJ, Charnock-Jones DS, Jauniaux E, 2009 Regulation of vascular growth and function in the human placenta. Reproduction 138: 895-902.

63. Fagiani E, Christofori G, 2013 Angiopoietins in angiogenesis. Cancer Lett 328: 18-26.

64. Baker PN, Krasnow J, Roberts JM, Yeo KT, 1995 Elevated serum levels of vascular endothelial growth factor in patients with preeclampsia. Obstet Gynecol 86: 815-821.

65. Aref S, Goda H, Abdelaal E, 2013 Circulating vascular growth factor (VEGF) angiopoietin-1 (Angi-1) and soluble tie-2 receptor in pregnancy complicated with pre-eclampsia: A prospective study. J Obstet Gynaecol India 63: 316-320.

66. Bhavina K, Radhika J, Pandian SS, 2014 VEGF and eNOS expression in umbilical cord from pregnancy complicated by hypertensive disorder with different severity. Biomed Res Int 2014: 982159.

67. Bolin M, Wiberg-Itzel E, Wikstrom AK, et al, 2009 Angiopoietin-1/angiopoietin-2 ratio for prediction of preeclampsia. Am J Hypertens 22: 891-895.

68. Park JE, Chen HH, Winer J, Houck KA, Ferrara N, 1994 Placenta growth factor. Potentiation of vascular endothelial growth factor bioactivity, in vitro and in vivo, and high affinity binding to Flt-1 but not to Flk-1/ KDR. J Biol Chem 269: 25646-25654.

69. Jang YS, Choi IH, 2014 Contrasting roles of different endoglin forms in atherosclerosis. Immune 14: 237-240.

70. Clark DE, Smith SK, He Y, et al, 1998 A vascular endothelial growth factor antagonist is produced by the human placenta and released into the maternal circulation. Biol Reprod 59: 1540-1548.

71. Guller S, Tang Z, Ma YY, Di Santo S, Sager R, Schneider H, 2011 Protein composition of microparticles shed from human placenta during placental perfusion: Potential role in angiogenesis and fibrinolysis in preeclampsia. Placenta 32: 63-69.

72. Conti E, Zezza L, Ralli E, et al, 2013 Growth factors in preeclampsia: a vascular disease model. A failed vasodilation and angiogenic challenge from pregnancy onwards? Cytokine Growth Factor Rev 24: 411-425.

73. Stubert J, Ullmann S, Bolz M, et al, 2014 Prediction of preeclampsia and induced delivery at $<34$ weeks gestation by SFLT-1 and PIGF in patients with abnormal midtrimester uterine Doppler velocimetry: a prospective cohort analysis. BMC Pregnancy Childbirth 14: 292.

74. Forest JC, Theriault S, Masse J, Bujold E, Giguere Y, 2014 Soluble Fms-like tyrosine kinase-1 to placental growth factor ratio in mid-pregnancy as a predictor of preterm preeclampsia in asymptomatic pregnant women. Clin Chem Lab Med 52: 1169-1178.

75. Kleinrouweler CE, Wiegerinck MM, Ris-Stalpers C, et al, 2012 Accuracy of circulating placental growth 
factor, vascular endothelial growth factor, soluble fms-like tyrosine kinase 1 and soluble endoglin in the prediction of pre-eclampsia: a systematic review and meta-analysis. BJOG 119: 778-787.

76. Bezerra PC, Leao MD, Queiroz JW, et al, 2010 Family history of hypertension as an important risk factor for the development of severe preeclampsia. Acta Obstet Gynecol Scand 89: 612-617.

77. Esplin MS, Fausett MB, Fraser A, et al, 2001 Paternal and maternal components of the predisposition to preeclampsia. N Engl J Med 344: 867-872.

78. Williams PJ, Broughton Pipkin F, 2011 The genetics of pre-eclampsia and other hypertensive disorders of pregnancy. Best Pract Res Clin Obstet Gynaecol 25: 405-417.

79. Yang J, Shang J, Zhang S, Li H, Liu H, 2013 The role of the renin-angiotensin-aldosterone system in preeclampsia: genetic polymorphisms and microRNA. J Mol Endocrinol 50: R53-66.

80. Regitz-Zagrosek V, Blomstrom Lundqvist C, Borghi C, et al, 2011 ESC Guidelines on the management of cardiovascular diseases during pregnancy: the Task Force on the Management of Cardiovascular Diseases during Pregnancy of the European Society of Cardiology (ESC). Eur Heart J 32: 3147-3197.

81. Lowe SA, Brown MA, Dekker GA, et al, 2009 Guidelines for the management of hypertensive disorders of pregnancy 2008. Aust N Z J Obstet Gynaecol 49: 242-246.

82. Mancia G, De Backer G, Dominiczak A, et al, 2007 Guidelines for the management of arterial hypertension: The Task Force for the Management of Arterial Hypertension of the European Society of Hypertension (ESH) and of the European Society of Cardiology (ESC). Eur Heart J 28: 1462-1536.

83. National Collaborating Centre for Women's and Children's Health (UK), 2010 NICE Clinical Guidelines, No. 107. In: Hypertension in pregnancy: The management of hypertensive disorders during pregnancy. London: RCOG Press. 2010

84. Kazimierak W, Kowalska-Koprek U, Karowicz-Bilinska A, et al, 2008 24-hour Holter measurement of blood pressure in pregnant women and effectiveness of the treatment. Ginekol Pol 79: 174-176.

85. Davis GK, Mackenzie C, Brown MA, et al, 2007 Predicting transformation from gestational hypertension to preeclampsia in clinical practice: a possible role for 24 hour ambulatory blood pressure monitoring. Hypertens Pregnancy 26: 77-87.

86. Giannubilo SR, Dell'Uomo B, Tranquilli AL, 2006 Perinatal outcomes, blood pressure patterns and risk assessment of superimposed preeclampsia in mild chronic hypertensive pregnancy. Eur J Obstet Gynecol Reprod Biol 126: 63-67.

87. Biswas A, Choolani MA, Anandakumar C, Arulkumaran S, 1997 Ambulatory blood pressure monitoring in pregnancy induced hypertension. Acta Obstet Gynecol Scand 76: 829-833.

88. Hermida RC, Ayala DE, Iglesias M, 2003 Circadian rhythm of blood pressure challenges office values as the "gold standard" in the diagnosis of gestational hypertension. Chronobiol Int 20: 135-156.

89. Brown MA, Mangos G, Davis G, Homer C, 2005 The natural history of white coat hypertension during pregnancy. BJOG 112: 601-606.

90. Brown M, 2013 Is there a role for ambulatory blood pressure monitoring in pregnancy? Clin Exp Pharmacol Physiol 41: 16-21.

91. Benedetto C, Zonca M, Giarola M, Maula V, Chiarolini L, Carandente F, 1997 24-hour blood pressure monitoring to evaluate the effects of nifedipine in pre-eclampsia and in chronic hypertension in pregnancy. Br J Obstet Gynaecol 104: 682-688.

92. Staessen JA, Asmar R, De Buyzere M, et al, 2001 Task Force II: blood pressure measurement and cardiovascular outcome. Blood Press Monit 6: 355-370.

93. Magee LA, Abalos E, von Dadelszen P, Sibai B, Easterling T, Walkinshaw S, 2011 How to manage hypertension in pregnancy effectively. Br J Clin Pharmacol 72: 394-401.

94. Szczepaniak-Chichel L, Tykarski A, 2012 Treatment of arterial hypertension in pregnancy in relation to current guidelines of the Polish Society of Arterial Hypertension from 2011. Ginekol Pol 83: 778-783.

95. Hogstedt S, Lindeberg S, Axelsson O, et al, 1985 A prospective controlled trial of metoprolol-hydralazine treatment in hypertension during pregnancy. Acta Obstet Gynecol Scand 64: 505-510.

96. Gruppo di Studio Ipertensione in Gravidanza, 1998 Nifedipine versus expectant management in mild to moderate hypertension in pregnancy. Gruppo di Studio Ipertensione in Gravidanza. Br J Obstet Gynaecol 105: 718-722.

97. Sibai BM, Barton JR, Akl S, Sarinoglu C, Mercer BM, 1992 A randomized prospective comparison of nifedipine and bed rest versus bed rest alone in the management of preeclampsia remote from term. Am J Obstet Gynecol 167: 879-884.

98. Sibai BM, Mabie WC, Shamsa F, Villar MA, Anderson GD, 1990 A comparison of no medication versus methyldopa or labetalol in chronic hypertension during pregnancy. Am J Obstet Gynecol 162: 960-966.

99. Cruickshank DJ, Robertson AA, Campbell DM, MacGillivray I, 1992 Does labetalol influence the development of proteinuria in pregnancy hypertension? A randomised controlled study. Eur J Obstet Gynecol Reprod Biol 45: 47-51.

100. Barton JR, Mercer BM, Sibai BM, 1997 The effect of nifedipine on urinary excretion of calcium in preeclampsia. Am J Perinatol 14: 609-612.

101. Rubin PC, Butters L, Clark DM, et al, 1983 Placebocontrolled trial of atenolol in treatment of pregnancy- 
associated hypertension. Lancet 1: 431-434.

102. Pickles CJ, Symonds EM, Broughton Pipkin F, 1989 The fetal outcome in a randomized double-blind controlled trial of labetalol versus placebo in pregnancy-induced hypertension. Br J Obstet Gynaecol 96: 38-43.

103. Pickles CJ, Broughton Pipkin F, Symonds EM, 1992 A randomised placebo controlled trial of labetalol in the treatment of mild to moderate pregnancy induced hypertension. Br J Obstet Gynaecol 99: 964-968.

104. Redman CW, 1976 Fetal outcome in trial of antihypertensive treatment in pregnancy. Lancet 2: 753-756.

105. Elhassan EM, Mirghani OA, Habour AB, Adam I, 2002 Methyldopa versus no drug treatment in the management of mild pre-eclampsia. East Afr Med J 79: $172-175$.

106. Weitz C, Khouzami V, Maxwell K, Johnson JW, 1987 Treatment of hypertension in pregnancy with methyldopa: a randomized double blind study. Int J Gynaecol Obstet 25: 35-40.

107. Molvi SN, Mir S, Rana VS, Jabeen F, Malik AR, 2012 Role of antihypertensive therapy in mild to moderate pregnancy-induced hypertension: a prospective randomized study comparing labetalol with alpha methyldopa. Arch Gynecol Obstet 285: 1553-1562.

108. Phippard AF, Fischer WE, Horvath JS, et al, 1991 Early blood pressure control improves pregnancy outcome in primigravid women with mild hypertension. Med J Aust 154: 378-382.

109. Ismail AA, Medhat I, Tawfic TA, Kholeif A, 1993 Evaluation of calcium-antagonist (Nifedipine) in the treatment of pre-eclampsia. Int J Gynaecol Obstet 40: 39-43.

110. Wide-Swensson DH, Ingemarsson I, Lunell NO, et al, 1995 Calcium channel blockade (isradipine) in treatment of hypertension in pregnancy: a randomized placebo-controlled study. Am J Obstet Gynecol 173: 872-878.

111. Darcie S, Leone CR, Calil VM, Prescinotti EP, Kahhale S, Zugaib M, 2004 Glycemia in newborns of hypertensive mothers according to maternal treatment. Rev Hosp Clin Fac Med Sao Paulo 59: 244-250.

112. Butters L, Kennedy S, Rubin PC, 1990 Atenolol in essential hypertension during pregnancy. BMJ 301: 587-589.

113. Sibai BM, Gonzalez AR, Mabie WC, Moretti M, 1987 A comparison of labetalol plus hospitalization versus hospitalization alone in the management of preeclampsia remote from term. Obstet Gynecol 70: 323-327.

114. Plouin PF, Breart G, Llado J, et al, 1990 A randomized comparison of early with conservative use of antihypertensive drugs in the management of pregnancy-induced hypertension. Br J Obstet Gynaecol 97: 134-141.

115. Cruickshank DJ, Campbell DM, 1990 Atenolol in essential hypertension during pregnancy. BMJ 301: 1103.
116. von Dadelszen P, Ornstein MP, Bull SB, Logan AG, Koren G, Magee LA, 2000 Fall in mean arterial pressure and fetal growth restriction in pregnancy hypertension: a meta-analysis. Lancet 355: 87-92.

117. Cockburn J, Moar VA, Ounsted M, Redman CW, 1982 Final report of study on hypertension during pregnancy: the effects of specific treatment on the growth and development of the children. Lancet 1 : 647-649.

118. Moar VA, Jefferies MA, Mutch LM, Ounsted MK, Redman CW, 1978 Neonatal head circumference and the treatment of maternal hypertension. Br J Obstet Gynaecol 85: 933-937.

119. Mutch LM, Moar VA, Ounsted MK, Redman CW, 1977 Hypertension during pregnancy, with and without specific hypotensive treatment. I. Perinatal factors and neonatal morbidity. Early Hum Dev 1: 47-57.

120. Mutch LM, Moar VA, Ounsted MK, Redman CW, 1977 Hypertension during pregnancy, with and without specific hypotensive treatment. II. The growth and development of the infant in the first year of life. Early Hum Dev 1: 59-67.

121. Ounsted MK, Moar VA, Good FJ, Redman CW, 1980 Hypertension during pregnancy with and without specific treatment; the development of the children at the age of four years. Br J Obstet Gynaecol 87: 19-24.

122. Bortolus R, Ricci E, Chatenoud L, Parazzini F, 2000 Nifedipine administered in pregnancy: effect on the development of children at 18 months. BJOG 107: 792-794.

123. Abalos E DL, Steyn DW, Henderson-Smart DJ, 2007 Antihypertensive drug therapy for mild to moderate hypertension during pregnancy. Cohrane Database Syst Rev 2007: 1; CD002252.

124. Magee LA, Elran E, Bull SB, Logan A, Koren G, 2000 Risks and benefits of beta-receptor blockers for pregnancy hypertension: overview of the randomized trials. Eur J Obstet Gynecol Reprod Biol 88: 15-26.

125. Nabhan AF, Elsedawy MM, 2011 Tight control of mildmoderate pre-existing or non-proteinuric gestational hypertension. Cochrane Database Syst Rev 2011: 7; CD006907.

126. Gaillard R, Steegers EA, Hofman A, Jaddoe VW, 2011 Associations of maternal obesity with blood pressure and the risks of gestational hypertensive disorders. The Generation R Study. J Hypertens 29: 937-944.

127. Task Force Members, 2013 ESH/ESC Guidelines for the management of arterial hypertension: The Task Force for the management of arterial hypertension of the European Society of Hypertension (ESH) and of the European Society of Cardiology (ESC). Eur Heart J 34: 2159-2219.

128. Hypertension in Pregnancy: The Management of Hypertensive Disorders During Pregnancy. National Collaborating Centre for Women's and Children's Health. London: RCOG Press; 2010. 
129. Magee LA, Cham C, Waterman EJ, Ohlsson A, von Dadelszen P, 2003 Hydralazine for treatment of severe hypertension in pregnancy: meta-analysis. BMJ 327 : 955-960.

130. Khedun SM, Maharaj B, Moodley J, 2000 Effects of antihypertensive drugs on the unborn child: what is known, and how should this influence prescribing? Paediatr Drugs 2: 419-436.

131. Solomon CG, Seely EW, 2011 Hypertension in pregnancy. Endocrinol Metab Clin North Am 40: 847-863.

132. Folic M, Folic N, Varjacic M, Jakovljevic M, Jankovic S, 2008 Antihypertensive drug for therapy for hypertensive disorders in pregnancy. Acta Medica Medianae 47: 65-72.

133. Churchill D, Beevers GD, Meher S, Rhodes C, 2007 Diuretics for preventing pre-eclampsia. Cochrane Database Syst Rev 2007: 1: CD004451.

134. Cooper WO, Hernandez-Diaz S, Arbogast PG, et al, 2006 Major congenital malformations after firsttrimester exposure to ACE inhibitors. N Engl J Med 354: 2443-2451.

135. Deva M, Kara T, 2012 ACE inhibitor fetopathy: a case series and survey of opinion amongst New Zealand paediatricians, obstetricians, neonatologists, and nephrologists. N Z Med J 125: 51-61.

136. Bullo M, Tschumi S, Bucher BS, Bianchetti MG, Simonetti GD, 2012 Pregnancy outcome following exposure to angiotensin-converting enzyme inhibitors or angiotensin receptor antagonists: a systematic review. Hypertension 60: 444-450.

137. Polifka JE, 2012 Is there an embryopathy associated with first-trimester exposure to angiotensin-converting enzyme inhibitors and angiotensin receptor antagonists? A critical review of the evidence. Birth Defects Res A Clin Mol Teratol 94: 576-598.

138. Duley L, Henderson-Smart DJ, Meher S, 2006 Drugs for treatment of very high blood pressure during pregnancy. Cochrane Database Syst Rev 2006: 3; CD001449.

139. Brogden RN, Sorkin EM, 1990 Ketanserin. A review of its pharmacodynamic and pharmacokinetic properties, and therapeutic potential in hypertension and peripheral vascular disease. Drugs 40: 903-949.

140. Buch J, 2010 Urapidil, a dual-acting antihypertensive agent: Current usage considerations. Adv Ther 27: 426-443.

141. Carles G, Helou J, Dallah F, Ibrahim N, Alassas N, Youssef M, 2012 Use of injectable urapidil in pregnancy-induced hypertension and preeclampsia. J Gynecol
Obstet Biol Reprod 41: 645-649.

142. Vigil-De Gracia P, Lasso M, Ruiz E, Vega-Malek JC, de Mena FT, Lopez JC, 2006 Severe hypertension in pregnancy: hydralazine or labetalol. A randomized clinical trial. Eur J Obstet Gynecol Reprod Biol 128: 157-162.

143. Baggio MR, Martins WP, Calderon AC, et al, 2011 Changes in fetal and maternal Doppler parameters observed during acute severe hypertension treatment with hydralazine or labetalol: a randomized controlled trial. Ultrasound Med Biol 37: 53-85.

144.Hennessy A, Thornton CE, Makris A, et al, 2007 A randomised comparison of hydralazine and mini-bolus diazoxide for hypertensive emergencies in pregnancy: the PIVOT trial. Aust N Z J Obstet Gynaecol 47: 279-285.

145. Wacker JR, Wagner BK, Briese V, et al, 2006 Antihypertensive therapy in patients with pre-eclampsia: A prospective randomised multicentre study comparing dihydralazine with urapidil. Eur J Obstet Gynecol Reprod Biol 127: 160-165.

146. Manzur-Verastegui S, Mandeville PB, Gordillo-Moscoso A, Hernandez-Sierra JF, Rodriguez-Martinez M, 2008 Efficacy of nitroglycerine infusion versus sublingual nifedipine in severe pre-eclampsia: a randomized, triple-blind, controlled trial. Clin Exp Pharmacol Physiol 35: 580-585.

147. Raheem IA, Saaid R, Omar SZ, Tan PC, 2012 Oral nifedipine versus intravenous labetalol for acute blood pressure control in hypertensive emergencies of pregnancy: a randomised trial. BJOG 119: 78-85.

148. Magee LA, Pels A, Helewa M, Rey E, von Dadelszen P, 2014 SOGC Hypertension Guideline Committee, 2014 Diagnosis, Evaluation, and Management of the Hypertensive Disorders of Pregnancy: executive Summary. J Obstet Gynaecol Can 36: 575-576.

149. Raheem IA, Saaid R, Omar SZ, Tan PC, 2012 Oral nifedipine versus intravenous labetalol for acute blood pressure control in hypertensive emergencies of pregnancy: a randomised trial. BJOG 119: 78-85.

150. Committee on Obstetric Practice, 2011 Committee Opinion no. 514: emergent therapy for acute-onset, severe hypertension with preeclampsia or eclampsia. Obstet Gynecol 118: 1465-1468.

151. Sibai BM, 2002 Chronic hypertension in pregnancy. Obstet Gynecol 100: 369-377.

152. Telang MA, Bhutkar SP, Hirwani RR, 2013 Analysis of patents on preeclampsia detection and diagnosis: a perspective. Placenta 34: 2-8. 